\title{
Analgesic activity of lagenaria siceraria root extract by tail flick method in albino mice
}

\author{
Kunjumon Dayana ${ }^{1}$, Megaravalli R Manasa ${ }^{2 *}$
}

${ }^{1}$ Tutor, ${ }^{2}$ Associate Professor, Dept. of Pharmacology, ${ }^{1}$ Pushpagiri Institute of Medical Sciences and Research Centre, Thiruvalla, Kerala, ${ }^{2}$ Karwar Institute of Medical Sciences, Karwar, Karnataka, India

*Corresponding Author: Megaravalli R Manasa

Email: dr.manasamr@gmail.com

\begin{abstract}
Introduction: Analgesics relieve pain which otherwise can cause distress and suffering. But analgesics like NSAIDs and opioids can cause side effects like gastric irritation, tolerance and dependence. Hence it is essential to develop new compounds with analgesic potential.

Objectives: To evaluate the analgesic potential of ethanolic extract (EE) of Lagenaria siceraria (L. siceraria) root by tail flick method in albino mice.

Materials and Methods: Animals were allocated to four groups. Group 1(control) was administered normal saline. Group 2 was given aspirin $40 \mathrm{mg} / \mathrm{kg}$ (Standard). EE of L. siceraria roots $100 \mathrm{mg} / \mathrm{kg} \mathrm{BW}$ was given to Group 3. Group 4 was given EE of L. siceraria roots 200 $\mathrm{mg} / \mathrm{kg}$ BW. All administrations were per oral. Analgesic potential was analysed by tail flick method.

Results: EE of L. siceraria roots $(100 \mathrm{mg} / \mathrm{kg} \mathrm{BW})$ increased the reaction time significantly at 15 minutes $(\mathrm{p}<0.001)$ in comparison with the control. Its analgesic potential was equivalent to standard. L. siceraria root extract $(200 \mathrm{mg} / \mathrm{kg} \mathrm{BW})$ increased the reaction time significantly at 15 and 60 minutes $(\mathrm{p}<0.001)$ in comparison with control. Its analgesic potential was comparable to Aspirin at 15 minutes and 60 minutes. The maximum activity was observed at 60 minutes.
\end{abstract}

Conclusion: The EE of L. siceraria roots possess analgesic activity in albino mice.

Keywords: L. siceraria, Analgesic, Albino mice, Tail flick.

\section{Introduction}

Pain is a sensation which is unpleasant but predominantly protective in nature. It can cause distress and suffering. ${ }^{1}$ Analgesics relieve pain selectively by central or peripheral mechanisms without affecting consciousness. The analgesic drugs available currently - opioids and nonsteroidal anti-inflammatory drugs (NSAIDs), are associated with number of adverse effects. Vomiting, constipation, respiratory depression, tolerance and dependence are common problems with opioids, whereas gastric mucosal damage and ulcer are seen with NSAID use..$^{2-4}$ Hence there is a necessity for new analgesic compounds devoid of adverse effects.

Plants with medicinal value have been a valuable source of new drugs because they are available in abundance and cause less adverse reactions. Lagenaria siceraria (L. siceraria) generally called bottle gourd is a medicinal plant. It is from Cucurbitaceae family. ${ }^{5}$ It grows throughout India and is widely used as a vegetable. ${ }^{6}$ It has been used as medicine traditionally in India, Brazil, European countries, China, Hawaiian island, etc for common ailments. ${ }^{7}$ It is reported to have antihyperglycemic, ${ }^{8}$ antihyperlipidemic, ${ }^{9}$ antioxidant, ${ }^{10}$ cardioprotective, ${ }^{11}$ immunomodulatory, ${ }^{12}$ antiinflammatory, ${ }^{13}$ diuretic ${ }^{14}$ activities. Its phytochemical screening has shown that it contains alkaloids, phenols, tannins, flavonoids and steroidal compounds. ${ }^{15}$

The search for a novel analgesic with favourable risk benefit profile is on-going because the analgesics currently in use even though highly efficacious are associated with many adverse reactions. Hence the current study was undertaken to analyse the analgesic potential of EE of L. siceraria roots by tail flick method in albino mice.

\section{Materials and Methods}

Preparation of Plant Extract: The dried roots of L. siceraria were powdered in an electrical blender. The dry powder was taken in soxhlet apparatus and extracted in ethanol. Rotary evaporator was used for concentrating the filtrate and ethanol elimination. The extract so obtained was stored in sterile bottles.

Chemicals: The standard drug - aspirin were procured from Dabur pharma Ltd, Tarapur, Thane. Ethanol and other chemicals were purchased from Sigma Aldrich Pvt Ltd, Bengaluru, India. All chemicals were of analytical grade.

Animals: Albino mice of both sex, 20 - 25g in weight and 78 weeks old were chosen. They were acquired from Central animal house, Sri Kaliswari college, Sivakasi, India. They were maintained at room temperature and $12 \mathrm{hr}$ light- dark cycle. They were served pellet diet and water ad libitum. The Institutional animal ethics committee approved the study.

Experiment: Albino mice were divided into 4 groups. Group 1 (control) was administered saline $(0.1 \mathrm{mg} / \mathrm{kg})$. Group 2 (Standard) was administered aspirin $40 \mathrm{mg} / \mathrm{kg}$. Group 3 was administered EE of L. siceraria root $100 \mathrm{mg} / \mathrm{kg} \mathrm{BW}$. Group 4 was administered EE of L. siceraria root $200 \mathrm{mg} / \mathrm{kg}$ BW. All administrations were per oral.

Analgesic Activity: The analgesic potential was evaluated by tail flick method (Radiant heat). ${ }^{16,17}$ The mice were placed in a restrainer with an opening for their tails. The proximal third of the tail was exposed to radiant heat. The response of mice either as withdrawal of tail (tail flick) or turning of head to one side was taken as the Reaction time. The reaction time was noted at 15, 30, 60 and 120 minutes after the control / standard / plant extract administration. 


\section{Statistical Analysis}

The data was stated as mean \pm standard error of mean (SEM). The data was analysed by one way ANOVA and Dunnets test as post hoc. $\mathrm{P}$ value $<0.05$ was considered significant.

\section{Results}

The reaction time (seconds) noted in various groups by tail flick (radiant heat) method at various time intervals is shown in Table 1. In both the control and test groups (EE of L. siceraria roots at $100 \mathrm{mg} / \mathrm{kg} \mathrm{BW}$ and $200 \mathrm{mg} / \mathrm{kg} \mathrm{BW}$ ), the reaction time has steadily increased from 15 minutes to 60 minutes. But at 120 minutes it has decreased. In the standard group (Aspirin), the reaction time has steadily increased from 15 minutes to 120 minutes.

It can be observed that in Group 3 (EE of L. siceraria roots $100 \mathrm{mg} / \mathrm{kg} \mathrm{BW}$ ), the reaction time has increased significantly at 15 minutes $(\mathrm{p}<0.001)$ in comparison with the control group. Its activity is comparable to the standard (Aspirin) at 15 minutes. (Table 1) Group 4 (EE of L. siceraria roots $200 \mathrm{mg} / \mathrm{kg} \mathrm{BW}$ ) exhibits statistically significant increase in the reaction time at 15 minutes and 60 minutes $(\mathrm{p}$ $<0.001)$ in comparison with control. The analgesic potential of the root extract at $200 \mathrm{mg} / \mathrm{kg}$ is comparable to Aspirin (Group 2) at 15 minutes and 60 minutes. The extract exhibits maximum activity at 60 minutes. (Table 1)

Table 1: Reaction time in seconds observed in tail flick method

\begin{tabular}{|l|c|c|c|c|}
\hline Groups & 15 minutes & 30 minutes & 60 minutes & 120 minutes \\
\hline 1. Control & $6.0 \pm 0.02$ & $19 \pm 0.08$ & $28 \pm 0.07$ & $22 \pm 0.09$ \\
\hline 2. Standard (Aspirin 40 mg/kg BW) & $23 \pm 0.03^{a^{* * *}}$ & $51 \pm 1.2^{\mathrm{a}^{* * *}}$ & $54 \pm 1.1^{\mathrm{a}^{* * * *}}$ & $58 \pm 0.04^{\mathrm{a}^{* * * *}}$ \\
\hline 3. EE of L. siceraria roots $(100 \mathrm{mg} / \mathrm{kg} \mathrm{BW})$ & $20 \pm 1.0^{\mathrm{a}^{* * * *}}$ & $21 \pm 0.09^{\mathrm{b}^{* * * *}}$ & $34 \pm 0.05^{\mathrm{b}^{* * * *}}$ & $11 \pm 0.02^{\mathrm{a}^{* * *}, \mathrm{~b}^{* * * *}}$ \\
\hline 4. EE of L. siceraria roots $(200 \mathrm{mg} / \mathrm{kg} \mathrm{BW})$ & $24 \pm 0.03^{\mathrm{a}^{* * *}}$ & $26 \pm 0.01^{\mathrm{b}^{* * * *}}$ & $41 \pm 0.06^{\mathrm{a}^{* * *}}$ & $14 \pm 0.04^{\mathrm{b}^{* * * *}}$ \\
\hline
\end{tabular}

Data is presented as mean \pm SEM. $*=\mathrm{P}<0.05, * *=\mathrm{P}<0.01, * * *=\mathrm{P}<0.001$. Superscripts (a) indicates comparison of data with control group while (b) is comparison with standard.

\section{Discussion}

The EE of L. siceraria roots was analysed for their analgesic potential in albino mice. The analgesic potential was compared with aspirin which is the standard drug used for this method. The screening method employed in this study was tail flick (radiant heat) method which is a specific screening model for centrally acting drugs. ${ }^{18}$

In current study, the EE of L. siceraria roots at both doses has steadily increased the reaction time from 15 minutes to 60 minutes. But this effect is not sustained at 120 minutes. In mice which received EE of L. siceraria roots $100 \mathrm{mg} / \mathrm{kg} \mathrm{BW}$, the reaction time has increased significantly at 15 minutes in comparison with control. Its analgesic potential is equivalent to the standard at 15 minutes. At the dose of $200 \mathrm{mg} / \mathrm{kg} \mathrm{BW}$, the extract shows significant increase in the reaction time at 15 and 60 minutes in comparison with control. Its activity is equivalent to Aspirin at 15 and 60 minutes. Maximum activity is noted at 60 minutes. These observations suggest that the EE of L. siceraria roots has analgesic potential.

Several studies have reported similar findings. In a study by Harini $\mathrm{K}$ and Jayasree $\mathrm{T}$, it was found that fruit extract of L. siceraria has analgesic activity. ${ }^{19}$ Gill NS et al have reported the analgesic activity of ethanolic seed extract of $\mathrm{L}$. siceraria. ${ }^{20}$ According to Shah BN and Seth AK, aqueous and ethanolic extract of L. siceraria fruits show analgesic activity in rats. ${ }^{21}$ Saha $\mathrm{P}$ et al also reported the antinociceptive potential of aerial parts of L. siceraria. ${ }^{22}$

The mechanism of this activity of EE of L. siceraria roots might be due to central action. This is because the extract had potent activity in tail flick method which is a specific test for screening centally acting analgesics. The analgesic property might be due the presence of phytoconstituents like alkaloids, tannins, phenols, flavonoids and steroidal compounds.

\section{Conclusion}

The findings of our study suggests that EE of L. siceraria roots possess analgesic activity in albino mice. However further studies are required to reveal the exact mechanism of analgesic action and to isolate the active constituents of the extract.

\section{Acknowledgements}

We thank Anjukam and Senthamari Selvi for their help and support.

\section{Funding: None.}

Conflict of Interest: None.

Ethical Approval: The Institutional Animal Ethics committee has approved this study.

\section{References}

1. Bhattacharya A, Agrawal D, Sahu PK, Kumar S, Mishra SS, Patnaik S. Analgesic effect of ethanolic leaf extract of moringa oleifera on albino mice. Indian J Pain. 2014;28:89-94.

2. Tripathi KD. "Opiod analgesics and antagonists." In: Essentials of medical pharmacology. 8th edition, New Delhi, Jaypee brothers medical publishers(P) Ltd, 2018:497- 514.

3. Brenner GM, Stevens CW. Drugs for pain, inflammation and arthritic disorders. In: Pharmacology. 4th edition, Philadelphia, Saunders, 2014: 314-329.

4. Yaksh TL, Wallace MS. "Opioids, analgesia and pain”. In: Brunton LL, Chabner BA, Knollmann BC. Goodman \& Gilman's The pharmacological basis of therapeutics. 12th edition, New York, Mc Graw Hill Companies Inc, 2011:481525 .

5. Sirohi P S, sivakami N. genetic diversity in cucurbits. Indian Hort. 1991;36: 45-463.

6. Tyagi N, Sharma GN, Shrivastava B. Medicinal value of Lagenaria siceraria: An overview. Int J Ind Herbs Drugs. 2017;2(3):36-43. 
7. Saha P, Mazumder UK, Haldar PK, Islam A, Kumar RBS Evaluation of acute and subchronic toxicity of Lagenaria siceraria aerial parts. Int J Pharma Sci Res. 2011;2):15071512.

8. Deshpande J. R. Beneficial effects of Lagenaria siceraria (Mol) Standley fruit epicarp in animal models. Indian J Exp Biol. 2008;46:234-242.

9. Saojia A.N. Antihyperlipidemic effect of the methanolic extract from Lagenaria siceraria Stand. Fruit in hyperlipidemic rats. J Ethnopharmacol. 2009;124:333-337.

10. Erasto P. Antioxidant activity and HPTLC profile of Lagenaria siceraria fruits Tanzania. J Health Res, 2009;11(2):79-83.

11. Hassanpour Fard M. (2008). Cardioprotective activity of fruit of Lagenaria siceraria (Molina) Sandley on doxorubicin induced Cardiotoxicity in rats. Int J Pharmacol.1-8.

12. Gupta G.L. Immunomodulatory effects of Lagenaria siceraria fruits in rats Pharmacognosy Magazine. 2008;4(16):234 -238.

13. Ghule B.V. (2006), Analgesic and AntiInflammatory activities of Lagenaria siceraria Stand. fruit juice extract in rats and mice, Pharmacognosy Magazine. 2(8).

14. Ghule B. V et al. (2007), Diuretic Activity of Lagenaria sicerira Fruit Extract in Rats. Indian J Pharm Sci. 2007;69(6):817-819.

15. Kumar A, Partap S, Sharma NK, Jha KK. Phytochemical, Ethnobotanical and Pharmacological Profile of Lagenaria siceraria: - A Review. J Pharmacogn Phytochemistry. 2012;1(3):24-31.

16. Patel PK, Sahu J, Chandel SS. A Detailed Review on Nociceptive Models for the Screening of Analgesic Activity in Experimental Animals. Int J Neurol Physl Ther. 2016;2(6):4450.
17. Milind P, Monu Y. Laboratory models for screening analgesics. Int Res J Pharm. 2013;4(1):15-19.

18. Ganeshpurkar A, Rai G. Experimental evaluation of analgesic and anti-inflammatory potential of Oyster mushroom Pleurotus fl orida. Indian J Pharmacol. 2013;45:66-70.

19. Harini K, Jayasree T. Evaluation of Analgesic Activity of Lagenaria Siceraria in Albino Rats. JMSCR. 2017;5(11):30316-30321.

20. Gill NS, Singh S, Arora R and Bali M. Evaluation of ethanolic seed extract of Lagenaria siceraria for their therapeutic potential. J Med Sci. 2012;12(3):78-84.

21. Shah BN, Seth AK. Screening of lagenaria siceraria fruits for their analgesic activity. Rom J Biol Plant Biol. 2010;55(1):2326.

22. Saha P, Mazumder UK, Haldar PK. Evaluation of Antiinflammatory and Antinociceptive Properties of L. siceraria Aerial Parts. IJPSR. 2015;6(5):874-881.

How to cite this article: Dayana $K$, Manasa M. R. Analgesic activity of lagenaria siceraria root extract by tail flick method in albino mice. Indian $\mathrm{J}$ Pharm Pharmacol. 2018;5(4):195-197. 